\title{
Gender and Occupational Mobility in Urban China during the Economic Transition
}

\author{
Yueping Song and Xiao-yuan Dong \\ Department of Economics Working Paper Number: 2011-01
}

THE UNIVERSITY OF WINNIPEG

Department of Economics

515 Portage Avenue

Winnipeg, R3B 2E9

Canada

This working paper is available for download from:

http://ideas.repec.org/s/win/winwop.html 


\title{
Gender and Occupational Mobility in Urban China during the Economic Transition ${ }^{1}$
}

\author{
Yueping Song \\ Renmin University, China \\ songyueping@ruc.edu.cn \\ Xiao-Yuan Dong \\ Corresponding author \\ University of Winnipeg, Canada \\ x.dong@uwinnipeg.ca
}

\begin{abstract}
:
This paper examines the gender patterns of occupational mobility in post-reform Urban China using a national representative dataset. The results reveal marked differences between married men and women: women are more likely than men to undergo lateral or downward occupational changes, but are less likely to experience upward mobility. The results also show that the public-sector restructuring has increased the incidence of downward occupational mobility, more for women than men. The analysis suggests that women are disadvantaged in the occupational mobility process by a variety of social and institutional factors.
\end{abstract}

Key words: Occupational mobility, Gender, Economic transition, Social networks

JEL Classification: J16, J63, C25, R20

\footnotetext{
1 The authors thank the Ford Foundation for its support of the post-graduate economic research and mentoring program for young women economists in China, and Yaohui Zhao for her valuable comments.
} 


\section{Introduction}

China's transition from a centrally planed to a market economy over the past three decades has fundamentally changed the mechanisms for labor reallocation and compensation in the urban sector. A large body of studies has emerged examining how the economic transition has affected the status of women relative to men in the labor market. While much of the research has been done on the gendered impacts for labor force participation, employment status, and wages, studies on occupational mobility remain sparse. The present paper sets to fill in the knowledge gap by examining the gender differences in occupational mobility in urban China with a national representative dataset collected in 2000 .

Occupational mobility is an important feature of the labor market in market economies where people change jobs to find a better match with ability and interest and a more rewarding career (Burdett 1978; Jovanovic 1979; Shaw 1987; Sicherman and Galor 1990). Understanding occupational mobility is important for the analysis of wage movement and occupational attainment. In transition economies, increased occupational mobility is a major labor market outcome of the reforms. The public-sector restructuring and the emergence of the private sector bring about massive labor reallocation both within and between firms, sectors, industries and regions. ${ }^{2}$ The structural adjustments create new opportunities for career advancement and, at the same time, also destroy millions of positions and force people to move to occupations that have a lower skill requirement or offer a lower pay (Sabirianova 2002). The patterns of occupational

${ }^{2}$ Dong and $\mathrm{Xu}$ (2009) document the massive labor adjustments following the public-sector restructuring in 1997 in China. For the labor market restructuring in Central and East European countries and the countries of the Commonwealth of Independent States, see Faggio and Konings (1999), Brown and Earle (2002) and Broadman and Recanatini (2003) and Konings and Walsh (2003). 
mobility have important implications to economic well-being.

Until recently, the research on occupational mobility in post-reform China was, for the most part, the undertaking of sociologists interested in social stratification. ${ }^{3}$ Cao and $\mathrm{Hu}$ (2007) study gender differences in the reasons of occupational mobility in urban China using data collected from six coastal cities in 1997. They find that, compared to married men, married women are less likely to undertake career-oriented job changes, but are more likely to change jobs to meet family needs or to encounter involuntary job termination, and that the gender differences in occupational mobility increased during the reform period. The present study extends the work by $\mathrm{CaO}$ and $\mathrm{Hu}$ in three aspects. First, we focus on the directionality of occupational mobility and distinguish four types of mobility: 1) being job stayers; 2) downward changes; 3) lateral changes, and 4) upward changes. We estimate the determinants of occupational mobility directions and explore the underlying sources of the gender gaps in occupational mobility. Second, our data are from a survey that covers all Chinese provinces except for Ningxia and Qinghai, overcoming the regional limitation of the study by Cao and $\mathrm{Hu}$ (2007). Finally, our data was collected in December 2000, permitting a close look at the impact of the public-sector restructuring, the radical phase of China's urban labor market reform, launched in 1997.

For a preview, the estimates reveal marked differences between men and women in occupational mobility. Women are more likely than men to undergo lateral or downward occupational changes, but are less likely to experience upward moves. The estimates also show that the public-sector restructuring sharply increases the probability of downward mobility, more for women than men. The analysis suggests that women's ability to buffer

3 For a literature survey, see Bian (2002). 
against market shocks and advance their careers is limited by a variety of cultural and institutional factors, such as societal expectation of gender role, unequal access to social networks and social protection and assistance, and discriminatory practices on the part of employers. The results of this paper support the growing body of literature demonstrating that the process of economic transition is not gender-neutral.

\section{Literature Review}

\subsection{Gender and Occupational Mobility in Established Market Economies}

Much of the research on occupational mobility has been done for established market economies, where occupational mobility is largely driven by the considerations of job matching and career mobility. The job matching theory regards occupational mobility as a means for workers and firms to overcome incomplete information and market uncertainty (Jovanovic, 1979). The theory predicts a negative effect of job tenure on mobility because the match between rewards and ability improves over time. The career mobility theory focuses on the role of human capital investment for career advancement (Sicherman and Galor, 1990). In accordance with this theory, an individual allocates the finite lifetime between education and various occupations in order to maximize the expected life time earnings. The individual chooses the optimal quitting time for a job and thus part of returns to education is in the form of higher probabilities of occupational advancement. Other things being equal, more educated individuals are more likely to be promoted within the firm or move to another firm which offers a higher paying job. The career mobility theory also predicts a positive effect of job tenure on occupational mobility; individuals with higher seniority acquire more skills and experience and therefore they are more likely to be promoted. 
Recent advances in social capital theory have drawn attention to the ways individuals' social networks affect occupational mobility. It is widely noticed that access to social networks improves the chances of obtaining a good job offer or receiving a promotion. ${ }^{4}$ One explanation for this is that social networks can potentially improve the quality of the match between workers and jobs by providing workers with information about the workplace prior to being hired and reducing the employer's uncertainty about workers' productivity (Datcher 1983; MaCall 1988; Simon and Warner 1992). An alternative explanation for the role of social networks is favoritism; employers may prefer well-connected workers in hiring and promotion, regardless of their productivity (Granovetter 1974; Corcoran, Datcher and Duncan 1980). Theoretically, the informational role of social networks is consistent with the expected behaviors of workers and firms in efficient factor markets while the favoritism hypothesis may find support from organizations that pursue non-economic objectives.

Job matching and career mobility are not the only causes for occupational mobility; technological progress, business cycles and policy changes (e.g. economic deregulation and trade liberalization) also bring about occupational changes, often of involuntary nature such as lay-offs. Voluntary and involuntary moves tend to affect wage growth differently, with the former being associated with wage growth and the latter often resulting in wage losses (Mincer 1986; Keith and McWilliams 1999). This difference between voluntary and involuntary moves is due to the fact that the reservation wage is usually higher for a quitter than a laid-off worker. The quitters are likely to undertake job search while stilled employed, whereas the laid-off worker may engage in job search after separation-while unemployed. Moreover, involuntary separation associated with

${ }^{4}$ See Lin (1999) for a literature survey on the subject. 
structural adjustments may render past human capital investment partly or entirely obsolete, while voluntary moves are not so "destructive".

Analysts have long recognized that women experience less upward occupational mobility than men during their careers, and the gender difference in occupational mobility is a main source of the gender wage gap in market economies (Lazear 1995). The gender differences in occupational mobility are often attributed to the differences in men's and women's labor market behaviors due to the societal expectation that men are the breadwinner and women are the caretaker. Women encounter workforce interruptions associated with child bearing and rearing, and women's intermittent labor force participation may reduce their human capital investment and thereby their chances of occupational upgrading (Mincer and Polachek, 1974; Jones and Makepeace, 1996; Royalty 1998). Women also tend to choose different career patterns from men because they value certain aspects of jobs, such as flexible working hours due to their household responsibilities (Becker 1957; Polachek, 1980). Given the trade-off between wages and skill levels and desire to work part-time/flexible hours, women are arguably more likely than men to choose occupations that do not require much human capital investment or such investment will not depreciate from workforce interruptions. Moreover, men and women may change jobs for different reasons (Kahn and Griesinger, 1989). Men are more likely than women to leave the firm if not promoted; in contrast, women are more likely to quit for family reasons (following husbands or taking care of children or elderly parents). Because workers who quit for economic reasons are more likely than those who quit for non-economic reasons to search for new jobs while still employed, the former should have a higher probability of receiving a better job offer than the latter (Keith and 
McWilliams 1999).

In addition to social gender norms, women's labor market opportunities are also limited by other institutional constraints. Feminist scholars contend that due to gender segregation and domestic responsibilities, personal contacts and informal information are less accessible to women than men, thereby hampering women's labor market outcomes (King and Manson, 2001; Timeberlake, 2005). Studies find that men were more active than women in job search while still employed and employed job search is instrumental for wage growth (Keith and McWilliams 1999), and that men also spent more time contacting friends and relatives than women for job search (Jones 1989). Due to the gender differences in search activity, voluntary job mobility may have a bigger positive effect on men's career advancement than women's.

The gender bias of employers in promotion and hiring is another widely recognized institutional factor that may contribute to the gender differences in occupational mobility. Analysts have noticed that women have less chance of being promoted to higher job levels than men and termed the phenomenon the "glass ceiling" effect. Lazear and Rosen (1990) explain the employers' bias against women in promotion by the differences between men and women in the value of non-market activities. They argue that because women have a comparative advantage in non-market activities and consequently face greater work-family conflict than men, the optimal response on the part of an employer is to set tougher promotion criteria for women than men. Krowas (1993) and Jones and Makepeace (1996) find evidence supporting the "glass ceiling" argument. An alternative explanation for the gender differences in upward mobility is the "dead-end" argument. In light of this argument, women are less likely to be found in 
higher level jobs than men because employers are reluctant to hire women for jobs that offer opportunities for promotion. Groot, Maassen and Brink (1996) find evidence consistent with the "dead-end" explanation.

Analysts have also noticed that job separation from regulated sectors has a larger negative effect on women's wage growth than men's (Maxwell and D'Amico, 1986; Madden, 1987; Crossley, 1994). These studies find that workers who are separated from the sector paying economic rents (e.g., the unionized sector) and subsequently find new jobs in competitive sectors endure wage losses because the pre-displacement wage overstates market worth for these workers, and the wage losses are particularly pronounced for women. In light of the empirical evidence that the gender earnings gap is relatively small in unionized organizations where wage rules stipulated in collective bargaining agreements restrain managerial discretions (Hirsch and Schumacher, 1998; Elvira and Saporta, 2001), women displaced from the unionized sector would lose not only the rents accrued to all union members but also the gender-specific protection provided by the union. Thus, women are more likely than men to undergo downward occupational mobility following economic deregulation.

\subsection{Economic Transition and Women's Wages and Employment in Urban China}

Prior to reforms, almost all working-age men and women in urban China joint the labor force after school graduation. The job was assigned by the government and guaranteed for life while the wage structure was centrally determined, primarily on the basis of workers' education and seniority (Korzec, 1992). Labor mobility rates were thus very low. In the socialist era, women's status in society was improved considerably. Chinese women's labor force participation rates were among the highest in the world and 
the gender earnings gap in China was remarkably small by international standards (Croll, 1983). However, sex segregation was prevalent; women were crowded into the overstaffed clerical and low-level administrative occupations and overrepresented in urban collectives, which offered lower pay and fewer benefits than did state-owned enterprises (SOEs) (Ngo, 2002). Women were also underrepresented politically despite that Communist party membership played a pivotal role in career advancement in the pre-reform era (Walder 1986).

In the late 1970s China began its transition to a market-oriented economy with a gradual approach. The wage-setting policies of SOEs became more decentralized; the managers of state enterprises were granted autonomy in hiring and promotion; workers who entered the labor force after 1986 were placed on short-term contracts instead of being offered permanent employment (Friedman 1996). The growth of rural township-village enterprises (TVEs), private firms and foreign invested companies attracted workers from the state sector as well as rural areas (Dong and Bowles 2002). The labor market reforms provided workers with greater freedom to pursue voluntary occupational changes. The pace of market reforms accelerated in the 1990s. In late 1992, the central government formally endorsed private property rights and initiated ownership reforms to SOEs. In 1994, a new labor law was passed sanctioning the right of employers to dismiss workers. In 1997, the government launched a large-scale labor retrenchment program in an attempt to revitalize SOEs. The SOE-sector restructuring has brought about massive labor reallocation both within and between sectors, industries and regions, bringing an end to the era of "iron rice bowl" for Chinese urban workers (Giles et al. 2006; Dong and Xu 2009). 
The economic transition has brought about rapid economic growth and significant improvement in the standards of living for Chinese workers. However, studies suggest that the transition has not benefited men and women equally. Wages have grown faster for men than women, and consequently the gender wage gap have increased markedly in the post-reform period (Maurer-Fazio et al. 1999; Gustafsson and Li, 2000; Zhang et al. 2008). Moreover, women were laid off at higher rates than men and experienced greater difficulty finding re-employment in the private sector (Appleton et al, 2002). In consequence, women's unemployment rates were higher than men's and their unemployment spells were longer (Giles, Park, and Cai 2006; Du and Dong 2008; Ding, Dong and Li, 2009). Women have also withdrawn from the labor force in larger numbers since the 1990s (Maurer-Fazio, Hughes and Zhang 2007). More and more married women are changing jobs from formal into informal sectors where wages are low, working conditions are poor, and social security and protections are largely unavailable (Yi and Chien 2002; Yuan and Cook 2009). Studies also indicate that, as with displaced union workers in established market economies, women suffered a larger decrease in compensation in the process of labor reshuffling from the public to the private sector $(\mathrm{Du}$ and Fan 2005; Knight and Li 2006; Zhang and Dong 2008).

In the remainder of the paper, we evaluate the impact of economic transition on women's status in the labor market by exploring the differences between married men and women in the directions of occupational mobility in the post-reform period.

\section{Conceptual Framework and Empirical Methodology}

We distinguish four types of occupational mobility based on the change in the Socio-Economic Index (SEI) of 3-digit occupations: 1) job stayers; 2) downward 
mobility; 3) lateral mobility; and 4) upward mobility. We propose that in the post-reform period, married women are more likely to experience job turbulence and downward occupational changes than their male counterparts, but are less likely to undergo upward changes, for four main reasons. First, due to the declining influence of socialist ideology, the Confucian patriarchal values that were suppressed to a certain degree in the socialist era have reemerged in the post-reform era, leading to more widespread acceptance of traditional gender role within families (Summerfield 1994; Yee, 2001). As Cao and Hu 2007) show, in post-reform urban China, married men were more likely than married women to change job for career advancement, whereas women displayed a greater tendency to change job to attend family matters. The gender differences in voluntary occupational changes are pointed as likely sources of the gender gap in upward mobility (Keith and McWilliams 1999).

Secondly, women have limited access to social networks. In the post-reform era, private information networks and personal connections (guanxi) became increasingly important for job security and career advancement (Bian 1997; Giles et al. 2006). People gathered information and developed personal connections through parents, spouses, relatives, friends, and political affiliations. Du and Dong (2009) find that relatives and friends were a more effective job search channel for men than women in post-restructuring urban China. Women's political under-representation may also handicap women in the labor market. Although the reform has diminished the importance of political royalty for career advancement, Communist party membership remains an important means to buffer against job instability and promote career opportunities (Walder 1995; Bian, Shu and Logan 2001). 
Thirdly, social protections and reemployment assistance are arguably more accessible to men than women, largely due to pre-reform sex segregation. Historically, women were concentrated in the collective sector. Compared to SOE workers, collective workers were more vulnerable to economic shocks and thereby lay-offs since urban collectives had been cut off from state subsidies long before SOEs. And many SOEs tried to adjust the workforce through re-deployment instead of outright lay-offs to minimize the adverse effect of restructuring on workers, especially in the early 1990s (Friedman 1996), while such moderate restructuring options were generally not feasible for urban collectives. Moreover, during the restructuring, a reemployment program was introduced, which provided displaced workers with basic living allowances, training and job replacement services and paid the premiums on their pensions, unemployment, and health insurance (Lee, 2000). With the social assistances, displaced workers were able to search longer and search more effectively for jobs that met their expectations, thereby minimizing downward occupational moves. However, the reemployment program targeted primarily displaced state workers. ${ }^{5}$ The lack of access to social protection and assistance by non-state workers in conjunction with the historical pattern of sex segregation may further disadvantage women in the post-restructuring labor market. ${ }^{6}$

Lastly, the incidence of gender discrimination in the urban labor market has become more widespread (Parish and Busse 2000) as the market reform substantially reduced the state's regulatory power to protect women. The rising incidence of gender discrimination

${ }^{5}$ For instance, in 1999, more than 95 percent of displaced workers in SOEs entered the reemployment program, with 79 percent of them receiving the full amount of living subsidies. By contrast, less than one-third to one-fifth of their counterparts in collectives and other types of enterprises had access to such programs (Dong, 2003).

${ }^{6} \mathrm{Du}$ and Dong (2009) find that the probability of reemployment was significantly lower for displaced women from urban collectives than their counterparts from SOEs. 
would exacerbate the glass ceiling phenomenon and push more women into the occupations of dead-end nature. Gender discrimination may become particularly prevalent in the post-restructuring period, given that high unemployment rates in this period may taper employers' concern about the negative economic consequences of discriminatory practices. Thus, women may be more likely than men to move to occupations with lower socio-economic status following the restructuring.

We will test the conjectures laid out above using multinomial logit regression techniques. We first estimate simultaneously the determinants of job changes and directions of occupational mobility with the following model:

$$
\ln \left(\frac{P_{j}}{P_{0}}\right)=\beta_{0}+\beta_{1} G+\lambda^{\prime} X+\gamma^{\prime \prime} Z
$$

where $P_{j}$ stands for the probability of the $j$-th type of mobility with $j=0$ for being a job stayer, $\mathrm{j}=1$ for downward mobility, $\mathrm{j}=2$ for lateral mobility, and $\mathrm{j}=3$ for upward mobility. The Greek letters are unknown parameters; $G$ is a gender dummy for women; $X$ is a vector of variables measuring individual characteristics such as human capital, social networks, family duties, ownership type of the employer, and so on, and $Z$ is a vector of proxy variables for market environment.

We next estimate the determinants of mobility directions for the job movers using the following model:

$$
\ln \left(\frac{P_{j}}{P_{0}}\right)=\beta_{0}+\beta_{1} G+\alpha^{\prime} W+\lambda^{\prime} X+\gamma^{\prime \prime} Z
$$

Where $\mathrm{j}=0$ for downward mobility, $\mathrm{j}=1$ for lateral mobility, and $\mathrm{j}=2$ for upward mobility; $X$ and $Z$ are the same as in equation (1), and $W$ is a vector of dummy variables 
for the reasons of occupational change. ${ }^{7}$ Following Cao and $\mathrm{Hu}$ (2007), we classify the reasons of occupational mobility into five categories: 1) career development; 2) family reasons; 3) company reassignments; 4) involuntary separation; and 5) unspecified reasons. The occupational changes due to the first two reasons are worker-initiated moves; the differences in men's and women's self-initiated occupational changes are indicative of their differences in preference. Company reassignments and involuntary separation are employer-initiated occupational changes; company reassignments include promotion, job transfers and redeployment, ${ }^{8}$ and involuntary separation consists of mandatory early retirement, lay-offs and job losses as a result of company bankruptcy. The gender differences in employer-initiated occupational changes reflect differences in the ways men and women are treated. The estimates of the variables for mobility reasoning provide information for assessing the extent to which any gender differences in the direction of occupational mobility can be attributed to differences in men's and women's quitting behavior and to differences in employers' attitudes toward men and women, holding constant individual and market characteristics.

Lastly, we explore if there are any differences in gender patterns of mobility between those who changed occupations through company reassignments and those who found new positions not through former employers' arrangement (i.e. those who move to seek career development, to attend family needs, or change occupations as a result of involuntary separation or unspecified reasons). The former case represents administratively managed job match whereas in the latter case job match is achieved, for the most part, through market mechanisms. Becker (1957) contends that employer taste

${ }^{7}$ Equations (1) and (2) offer a sensitivity check for the independence of irrelevant alternatives assumption.

${ }^{8}$ Disaggregate information on company reassignments is, however, unavailable. 
discrimination is incompatible with market competition. We test whether gender disparities are more pronounced for administrative mach than non-administrative match.

\section{Data and Variables}

The data set we use is drawn from the Second Survey on Social Status of Chinese Women undertaken jointly by All China Women Federation (ACWF) and China's National Bureau of Statistics in December 2000. This survey covered all Chinese provinces and province-equivalent municipalities except for Ningxia and Qinghai. Using a multistage random sampling procedure, the survey organizers interviewed 19,449 men and women from both rural and urban areas. For the purpose of this paper, we focus on the urban residents who are married, aged between 18 and 55 years, and currently employed. To streamline the analysis, we ignore those who are either unemployed or have withdrawn from the labor force. Omitting observations with missing information, we have a sample of 3,058 men and 3,296 women for empirical analysis.

According to the survey, 30.2 percent of the workers in the sample have never changed job since entering the labor force, and among the remaining 69.8 percent job movers, about 63 percent have changed job only once and 37 percent have acquired the current job after 1996. Due to the data limitation, we focus on the change between a mover's first job and current job. Following the occupational mobility literature, ${ }^{9}$ the directions of mobility for job movers are determined by a comparison of the Socio-Economic Index (SEI) of the mover's first job and current job. ${ }^{10}$ The SEI provides

${ }^{9}$ Killingsworth and Reimers (1983) argue that while wage is an important feature of employment status, it does not completely capture the socio-economic prestige of an occupation. For example of ranking occupation status by the SEI, see Sicherman and Galor (1990) for established market economies and Sabirianova (2002) for transitional countries.

${ }^{10}$ While the respondent was asked to report all jobs he/she had worked and also to give 
the ranking of a 3-digit occupation according to the occupation's average years of schooling and average monthly earnings in the sample using a formula developed by Chunling Li (2005). ${ }^{11}$

The explanatory variables in $X$ include age and its squared term, years of schooling, years of actual labor market experience ${ }^{12}$ and its squared term, SEI of the first job, SEI of father's occupation, SEI of spouse's occupation, party membership, number of children, a dummy variable for acquiring the current job after 1996, and ownership types of the employers. The initial SEI controls for the status of the first job; those holding jobs with higher socio-economic status are less likely to quit or move upwardly, other things being equal. The socio-economic status of fathers and spouses and party membership are proxy variables for access to social networks. Party membership is measured by a dummy variable. To avoid potential reverse causality between party member and promotion, the variable for party membership for movers is defined based on whether he/she was a Communist party member before obtaining the current job. The number of children is a proxy for domestic responsibility. The dummy for acquiring current job after 1996 is introduced to discern the effect of the public-sector restructuring. Ownership types are

the main reasons for leaving each job, the responses of the workers who had moved more than once for earlier job changes were fairly incomplete.

${ }^{11} \mathrm{Li}$ (2005) derived the SEI for 81 3-digit occupations using data from the Contemporary Chinese Social Structure Evolution Survey conducted by China Academy of Social Sciences in 2001. The survey generated a sample of 6,193 individuals aged between 16 and 70 years from 12 provinces. The respondents were asked to rank the prestige of each occupation in a scale from zero to 100. Li then regressed the mean prestige score of each occupation on the occupation's average years of schooling and average monthly earnings, and obtained the following formula:

$\mathrm{SEI}=10.868+3.496 \overline{x_{1}}+0.589 \overline{x_{2}}$, where $\overline{x_{1}}$ is average years of schooling and $\overline{x_{2}}$ is average monthly income. Using the estimates of this formula, we compute the SEI for 79 occupations and report the results in Appendix.

${ }^{12}$ Labor market experience for movers is number of years in the labor force prior to acquiring the current job. 
measured by three dummy variables, respectively, for urban collectives, private and foreign companies, and other ownership types (primarily self-employment and family-run business), with state organizations (SOEs and government organizations) as the base category. The explanatory variables in $Z$ include proportion of SOE employment in a province and seven regional dummies. The proportion of SOE employment is obtained from China's Statistical Yearbook (NBS, 2001). The definitions for regions are provided in the notes of Table 2 .

\section{Empirical Results}

\subsection{Descriptive Statistics}

Table 1 presents the distributions of occupational mobility by direction and by reason. With respect to the directions, 30.2 percent of the workers in the sample had never changed job at the time the survey was done; 28.1 percent had moved downwardly; 18.8 percent had made lateral moves; and 22.9 percent had experienced upward mobility. The gaps between women and men are noticeable: compared to men, the proportion of women is 4.0 percentage points lower for being a job stayer, 5.6 percentage points higher for downward mobility, 3.4 percentage points higher for lateral mobility, and 4.9 percentage points lower for upward mobility. Regarding to the reasons of occupational mobility, 22.2 percent of the movers changed jobs for career development; 15.9 percent changed jobs for family reasons, 39.6 percent changed jobs through company reassignments; and 17.2 percent changed jobs due to involuntary separations. It is noteworthy that company-reassigned job change is predominately a phoneme of the public sectors as it is evident that 77.3 percent of the cases occurred in the state sector, 16.7 in the collective sector, and the remaining 6 percent in the two private sectors. There 
are also marked differences between women and men: the distribution of women is 4.2 percentage points lower than that of men for career-oriented changes, 9.5 percentage points higher for family-oriented changes, 10.7 percentage points lower for company arranged changes, and 4.6 percentage points higher for involuntary separation. ${ }^{13}$

Table 2 presents mean values of the explanatory variables for individual and market characteristics in $X$ and $Z$. As can be seen from the table, the differences between men and women in human capital characteristics are small; men's age, years of schooling and initial SEI are slightly higher than women's, and also, interestingly, men's and women's labor market experiences are almost identical. Thus, unlike women in established market economies, workforce interruptions are not a likely source for any gender differences in occupational mobility in urban China. There are, however, discernible gender differences in other characteristics. Only 7 percent of the women had party membership prior to the latest job change while the proportion for men is 15 percent. With respect to the ownership type of employers, women were over-represented in urban collectives, although the distributions of men and women in two types of private ownership were similar. The percentage of women who changed job after 1996 is 7 percentage points higher than that of men, indicating that women experienced greater job turbulence following the restructuring. As for the relative status between spouses, the spouses of women have higher SEI scores than the spouses of men, which are consistent with traditional marriage norms.

13 The information on the reasons of occupational mobility is available only for 70 percent of the movers. To check the sensitivity of the estimates to the missing observations, we also estimated equation (2) using a sample including all movers and adding the observations with missing information on mobility reasoning to the base group of changing occupations for unspecified reasons. The results are substantively similar to those presented in Table 4 and are available upon request. 


\subsection{Regression results}

The multinomial logit models of occupational mobility determination are estimated by maximum likelihood estimation (MLE) techniques. We present the marginal effects of each explanatory variable derived from the multinomial logit estimates and standard errors robust to heteroscedasticity and clustering by province in Tables 3 to 5 . Table 3 presents the estimates of occupational mobility determination for job stayers and movers combined. Part I of the table reports the overall gender gaps obtained by regressing the mobility types on the gender indicator and regional dummy variables only. The estimates show that compared to men, women are 3.8 percent less likely to be a job stayer, 5.5 percent more likely to experience downward mobility, 3.4 percent more likely to experience lateral changes, and 5.0 percent less likely to move upwardly. All the gender differences are significant at the $1 \%$ level.

Part II of Table 3 reports the estimates of equation (1) which controls for all individual and market characteristics measured by the variables in $X$ and $Z$. Before commenting on the estimates of gender indicator, we take a look at the estimates of covariates. With respect to human capital characteristics, we note that years of schooling and labor market experience are positively correlated with the probability of stayers and negatively with the probabilities of downward and lateral mobility, with the relations being significant at the $5 \%$ level or higher. These results suggest that human capital characteristics are important for minimizing job instability and downward mobility risks. Regarding the effects of social networks, the estimates show that having a father or a spouse with high socio-economic status or a party membership is particularly important for upward mobility; the marginal effects of these variables are statistically highly 
significant and numerically large. For instance, a 10-point increase in the SEI of father or spouse would increase the probability of upward mobility by 3 percent, and a party member's probability of upward mobility is 19.3 percent higher than a non-party member's. Spouses' SEI and party membership also significantly reduce the probability of downward mobility. Moreover, consistent with the conjecture that the restructuring forced workers to move to occupations that had less skill requirements and offered lower pay, the estimates show that those who acquired the current job after 1996 are 24.9 percent more likely to undergo downward mobility. The estimates for ownership variables show that, compared to those employed in the public sector, workers who had quitted or been displaced and subsequently found job in the urban collectives, private or informal sectors are more likely to experience downward mobility (by 10.6, 14.2 and 14.7 percent, respectively). In addition, we note that the probability of downward mobility is the highest for the Northeastern region, the region which is deemed China's industrial rust belt.

Based on the estimates of party member and ownership types we find that the gender difference in party membership at sample means attributes to a gender gap of 0.4 percent in downward mobility and a gap of 1.5 percent in upward mobility, and that the gender difference in the share of urban collectives adds 0.53 percent to the gap in downward mobility and 0.3 percent to the gap in upward mobility. It is evident that women's under-representation in Communist party and overrepresentation in the urban collective sector are a source of the gender gaps in occupational mobility. Nevertheless, the gender differences in observed characteristics apparently explain only a small part of the gender gaps in occupational mobility, given that controlling for the individual and 
market characteristics changes the gender gap in each type of occupational mobility only marginally, and all the gender gaps remain significant at the $1 \%$ level.

Table 4 presents the estimates of occupational mobility directions for job movers. As in Table 3, Part I of Table 4 reports the overall gender gaps obtained by controlling only for regional variations. The estimates reveal a gender gap of 3.7 percent in the probability of downward mobility and a gap of -3.5 percent in the probability of upward mobility, with both estimates being significant at the 5\% level or higher. Part II of the table reports the estimates of gender indicator and its interactive term with the dummy variable for acquiring current job after 1996 while controlling for individual and market characteristics in $X$ and $Z$. The estimates show that holding constant individual and market characteristics, the presence of gender disparity in downward mobility is primarily a post-restructuring phenomenon, whereas the gender gap in upward mobility was existent prior to the restructuring and the restructuring does not make any difference in this regard.

We next add the reasons of occupational changes to the regression and present all the estimates of equation (2) in Part III of Table 4. We find that controlling for reasons of change does not change the findings for downward mobility: the stand alone gender dummy remains statistically insignificant while the interactive gender dummy variable is still significant at the $1 \%$ level. The estimates show that other things being equal, women who acquired the current job after 1996 are 9.1 percent more likely than their male counterparts to undergo downward mobility but 7.7 percent less likely to move to occupations with the same socio-economic status. These findings are in line with the view that the public-sector restructuring increases the likelihood of downward 
occupational change more for women than men. Regarding upward mobility, however, both gender variables now become statistically insignificant, indicating that the gender gap in upward mobility is primarily a result of the differences in men's and women's specific causes of occupational changes. Indeed, we note that relative to movers for unspecified reasons, the probability of upward mobility is 13.2 percent higher for career-oriented moves and 18.4 percent higher for reassignments but 13.5 percent lower for involuntary separation and all the aforementioned estimates are significant at the $1 \%$ level. We also find that involuntary separation significantly reduces the probability of downward mobility, by 27 percent. Interestingly, family-oriented changes have no significant impact on the directions of occupational mobility-a result similar to the finding that family-oriented changes have no effect on wage growth by $\mathrm{Cao}$ and $\mathrm{Hu}$ (2007). Based on the estimates of statistical significance, the gender difference in career-oriented moves at sample means implies a gender gap of -0.6 percent in upward mobility while the gender differences in two types of employer-initiated moves yield a gap of 2.8 percent in downward mobility and a gap of -2.6 percent in upward mobility. Apparently, the difference in men's and women's career preference plays a less important role for explaining the gender gaps in mobility directions than the differences in the ways women and men treated by the employers.

Turning to other explanatory variables, we note that most of the estimates are similar to those obtained for job stayers and movers combined and presented in Table 3, confirming the robustness of the results. As expected, education reduces the likelihood of downward mobility and increases the likelihood of upward mobility. The estimates also confirm that having a father or a spouse with high socio-economic status and being a 
party member are imperative for minimizing the risk of downward mobility and maximizing the prospect of upward mobility. Moreover, other things being equal, individuals who changed job after 1996 have a higher probability of downward mobility. Relative to public-sector workers, workers in the collective and private sectors are more likely to experience downward mobility.

The estimates presented in Table 5 caste light on the differences in gender patterns of mobility directions between administrative job match and non-administrative match. For the case of administrative match (see the first three columns), the stand-alone gender dummy is insignificant for downward mobility but significant for lateral and upward mobility while the interactive gender dummy is insignificant for all three mobility types. The estimates indicate that among the movers by company reassignments, women are 6.9 percent more likely than men to change occupation horizontally, but are 10.6 percent less likely to move to occupations with higher socio-economic status. It is evident that women confront the glass ceiling in promotion and/or are crowded into the dead-end occupations. In contrast, among non-administratively matched movers, significant gender differences are found only for downward and lateral mobility in the post-restructuring period (9.8 and -9.5 percent, respectively). This result suggests that in the post-restructuring labor market, women job seekers face gender discrimination and therefore have no choice but accepting job offers with lower socio-economic status. Thus, women are disadvantaged in occupational mobility, regardless of whether occupational changes are managed administratively or through market mechanisms. Turning to the differences in other covariates, we find that education has a stronger positive effect on upward mobility for administrative match than non-administrative match. But the most striking difference is 
that the occupational status of father and spouse and party membership are way more important for reducing downward risk and increasing upward mobility in the case of administrative match than the case of non-administrative match. This finding is consistent with the view that nepotisms are more prevalent in an administrative regime than a market regime.

\section{Conclusions}

China's economic transition over the past three decades has greatly increased occupational mobility, creating new opportunities for career advancement and, at the same time, destructing existing jobs and inducing downward occupational changes. In this paper, we examine the gender patterns of occupational mobility in urban China using data derived from a recent, nationally representative survey. We find that that married women are more likely than their male counterparts to experience job instability and downward mobility, but are less likely to undergo upward occupational changes. We also find that women are more likely than men to choose occupations with lower socio-economic status as a coping strategy following the public-sector restructuring. Our

analysis suggests that women are disadvantaged in the occupational mobility process by a variety of social and institutional factors. Chief among these constraints are societal gendered role expectations, unequal access to social resources associated with women's political under-representation, unequal entitlements to social protection and assistance resulted from pre-reform sex segregation, and gender discrimination in the process of promotion and recruitment. As a result of these social and institutional constraints, women's status relative to men's in the labor market has worsened during the economic transition. 
In addition to the findings on gender disparities, our analysis also generated several important results regarding the operation of China's urban labor market. We find human capital to be important in the occupational mobility process: occupational mobility falls with labor market experience while education reduces the risk of downward mobility and improves the chance of career advancement. Our results also confirm that family connections and political affiliations with the ruling Communist party are important for securing and promoting job and career opportunities, especially in the traditional administrative labor regime. Moreover, workers respond to the shocks of restructuring by choosing occupations with lower human capital requirements and lower pay; the incidence of downward occupational changes is more pronounced in non-state sectors than the state sector. These results shed new light on the sources and mechanisms of changes in socio-economic stratification and occupational mobility in transitional China. 


\section{References}

Appleton, S., Knight, J., Song, L. and Xia, Q. 2002. Labor retrenchment in China: determinants and consequences, China Economic Review, 13, pp.252-275.

Becker GS. 1957. The Economics of Discrimination. University of Chicago Press: Chicago, 1957.

Bian, Yanjie. 2002. "Chinese Social Stratification and Social Mobility," Annual Review of Sociology, 28: 91-116.

Bian, Yanjie. 1997. "Bringing strong ties back in: indirect ties, network bridges, and job searches in China." American Sociology Review, 63: 266-285.

Bian, Yanjie, X. Shu, and JR Logan. 2001. "Communist party membership and regime dynamics in China. Social Forces, 79: 805-842.

Broadman, Harry G., Recanatini, Francesca, 2003. Is Russia restructuring? Corporate Ownership \& Control, 1, 1: 50-71, Fall.

Brown, J. David, Earle, John S., 2002. Gross job flows in Russian industry before and after reforms: has destruction become more creative? Journal of Comparative Economics, 30, 1: 96-133.

Burdett, Kenneth. 1978. "A Theory of Employee Job Search and Quit Rates," American Economic Review 68:212-220.

Datcher, Linda. 1983. "The impact of informal networks on quit behavior." The review of Economics and Statistics 65(3): 491-495.

Cao, Yang and Chiung-Yin Hu. 2007. "Gender and Job Mobility in Post-socialist China: A longitudinal study of job changes in six coastal cities." Social Forces 85(4): $1535-1560$.

Corcoran, Mary, Linda Datcher, and Greg Duncan. 1980. "Information and influence networks in labor markets." In Five Thousand American Families: Patterns of Economic Progress, Vol. 8, ed. By G. Duncan and J. N. Morgan. Ann Arbor, Mich.: Institute for Social Research.

Croll, E. 1983. Chinese Women since Mao. London: UK: Zed Books

Crossley, T., Jones, S. and Kuhn, P. 1994. Gender differences in displacement cost, evidence and implications, Journal of Human Resources, 29(2), pp. 461-480

Ding Sai, Xiao-Yuan Dong and Shi Li, 2009. "Employment and Earnings of Married Women and Family Income Inequality during China's Economic Transition" 
Feminist Economics 15(3): 163-190.

Dong, Xiao-Yuan and Lixin Xu. 2009. "Labor Restructuring in China: Toward A Functioning Labor Market." Journal of Comparative Economics 37(2): 287-305, 2009

Dong, Xiao-yuan, Bowles, Paul, 2002. Segmentation and discrimination in China's emerging industrial labor markets. Chinese Economic Review, 13, 2-3: 170-196.

Dong, X-Y. 2003. China's urban labor market adjustment: a literature review. Working paper, World Bank, Washington, DC

Du, F. and Fan, X. 2005. Does unemployment matter to the earning differentials by gender? Journal of Nan Kai Economic Research (Chinese), No.2

Du, Fenglian and Xiao-yuan Dong. 2009. "Why Women Have Longer Unemployment Durations than Men in Post-Restructuring Urban China?" Cambridge Journal of Economics. 33(2): 233-252.

Elvira, M. and Saporta, I. 2001. How does collective bargaining affect the gender pay gap? Work and Occupations, 28(4), pp. 469-490.

Faggio, Giulia, Konings, Jozef, 1999. Gross job flows and firm growth in transition countries: evidence using firm level data on five countries. CEPR Discussion Paer, No. 2261.

Friedman, Barry L. 1996. "Employment and Social Protection Policies in China: Big Reforms and Limited Outcomes", Changes in China's Labor Market: Implications for the Future, pp. 151-166. U.S. Department of Labor, Bureau of International Labor Affair.

Giles, John, Park, Albert, Cai, Fang, 2006. How has economic restructuring affected China's urban workers? China Quarterly 185, March.

Giles, John, Albert Park, and Fang Cai. 2006. "Reemployment of Dislocated Workers in Urban China: The Roles of Information and Incentives." Journal of Comparative Economics 34(3): 582-607.

Granovetter, Mark. 1974. Getting a Job: A Study of Contacts and Careers. Cambridge, Mass.: Harvard University Press.

Groot, W. and Maassen van den Brink, H. 1996. "Glass ceilings or dead ends: job promotion of men and women compared", Economics Letters 53: 221-226.

Gustafsson, Björn and Shi Li. 2000. "Economic Transformation and the Gender Earnings Gap in Urban China." Journal of Population Economics 13(2): 305-29. 
Hersch, J. and W.K. Viscusi. 1996. "Gender differences in promotions and wages", Industrial Relations 35(4): 461-472.

Hirsch, B. and Schumacher, E. 1998. Unions, wages, and skills, The Journal of Human Resources, 33(1), pp. 201-219

Jones, Stephen R. G. 1989. "Job search methods, intensity, and effects." Oxford Bulletin of Economics and Statistics 5(3): 277-296.

Jones, D. R. and G. H. Makepeace. 1996. "Equal worth, equal opportunities: pay and promotion in an internal labour market." The Economic Journal 106: 401-409.

Jovanovic, Boyan. 1979. "Job matching and the theory of turnover," Journal of Political Economy 87(5): 972-990.

Kahn S. and H. Griesinger. 1989. "Female mobility and the returns to seniority: Should EEO policy be concerned with promotion?" American Economic Review 79: 300-304.

Keith, K. and A. McWilliams. 1999. "The Returns to Mobility and Job Search by Gender." Industrial and Labor Relations Review 52(3): 460-477.

Killingsworth, M. R. and C. W. Reimers. 1983. "Race, ranking, promotions and pay at a federal facility: a logit analysis." Industrial and Labor Relations Review37(1): 92-107.

King, E., and Mason, A. 2001. Engendering Development-Through Gender Equality in Rights, Resources, and Voice, A co-publication of the World Bank and Oxford University Press.

Knight, J. and Li, S. 2006. Unemployment duration and the earnings of reemployed workers in urban China, China Economic Review, 17(2): 103-119.

Konings, Jozef and Patrick Paul Walsh, 2003. Disorganization in the process of transition Firm-level evidence from Ukraine. Economics of Transition 7, 29-46.

Korzec, Michael, 1992. Labor and the Failure of Reform in China. St. Martin's Press/New York.

Krowas, John C. 1993. Time-dependent Changes in Gender-based Promotion. Differences, Economics Letters, 42: 87-90.

Lazear, E.P. 1995. Personnel Economics. Cambridge: The MIT Press.

Lazear, E.P. and Rosen, S. 1990. "Male-female wage differentials in job ladders", Journal of Labor Economics, 8(1): 106-123. 
Lee, H. 2000. Xiagang, the Chinese style of laying off workers, Asian Survey, 40(6): 914-37.

Li, Chunling. 2005. "The prestige stratification in current China-the measurement of career prestige and social economic index." Journal of Sociology Research, No.2: $1-21$.

Lin, Nan.1999. "Social networks and status attainment." Annual Review of Sociology 25: 467-487.

Madden, J. 1987. Gender differences in the cost of displacement: an empirical test of discrimination in the labor market, American Economic Review, 77(2), pp. 246-252

Maxwell, N. and D'Amico, R. 1986. Employment and wage effects of involuntary job separation: male-female differences, American Economic Review, 76(2), pp. $373-378$

Maurer-Fazio, Margaret; Rawski, Thomas G. and Zhang, Wei, 1999. "Inequality in the Rewards for Holding up Half the Sky: Gender-Wage Gaps in China's Urban Labor Market, 1988-1994.” China Journal, Vol. 41, January.

Maurer-Fazio, Margaret, James Hughes, and Dandan Zhang. 2007. "Gender, Ethnicity, and Labor Force Participation in Post-reform Urban China." Feminist Economics 13(3-4): 189-212.

McCall, J. J. 1988. Economics of information and job Search, Quarterly Journal of Economics, 26(2), pp. 646-679

Mincer, Jacob. 1986. "Wage Changes and Job Changes." Research in Labor Economics: A Research Annual, Vol. 8, Part A: 171-197.

Mincer, Jacob and Solomon Polachek. 1974. "Family investments in human capital: Earnings of Women.” Journal of Political Economy 82 (2): S76-S108.

National Bureau of Statistics, Statistical Yearbook of China. China Statistical Publishing House/Beijing, 2001.

Ngo, Hang-Yue, 2002. 'Trends in Occupational Sex Segregation in Urban China' in Gender," Technology and Development, 6(2), pp. 175-196.

Parish, William and Sarah Busse. 2000. "Gender and Work." In Chinese urban Life under Reform. Eds. Wenfang Tang and William Parish. Cambridge University Press. Pp. 209-231.

Polachek, Solomon. 1980. "Occupational self-selection: a human capital approach to sex differences in occupational structure." The Review of Economics and Statistics, 63(1): 60-69. 
Royalty, A. B. 1998. "Job-to-job and job-to-nonemployment turnover by gender and education level”, Journal of Labor Economics 16(2): 392-443.

Sabirianova, Klara Z. 2002. "The great human capital reallocation: a study of occupational mobility in transitional Russia." Journal of Comparative Economics 30: 191-217.

Shaw, Kathryn L. 1987. "Occupation change, employer change, and transferability of skills.” Southern Economic Journal 53 (3): 702-719.

Sicherman, N. and O. Galor. 1990. "A theory of occupational mobility", Journal of Political Economy 98(1): 169-192.

Simon, Curtis J. and John T. Warner. 1992. "Matchmaker, matchmaker: the effect of old boy networks on job match quality, earnings, and tenure." Journal of Labor Economics, 10(3): 306-330.

Summerfield, Gale. 1994, "Economic Reform and the Employment of Chinese Women' in Journal of Economic Issues, Vol. 28, No. 3, pp. 715-732.

Timberlake, S. 2005. Social capital and gender in the workplace, Journal of Management Development, 24(1): 34-44.

Walder, Andrew G. 1995. "Occupational mobility and the Communist Political Order", American Sociological Review 60(3): 309-328.

Walder, Andrew G. 1986. Communist Neo-Traditionalism: Work and Authority in Chinese Industry. Berkeley: University of California Press.

Yuan, Ni and Sarah Cook. 2009. "Gender patterns of informal employment in post-restructuring urban China." Unpublished manuscript.

Yee, J. 2001. Women's changing roles in the Chinese economy, The Journal of Economics 27(2), pp. 55-67

Yi, Chin-Chun and We-Yin Chien. 2002. "The linkage between work and family: female's employment patterns in three Chinese societies." Journal of Comparative Family Studies 33: 451-474.

Zhang Liqin and Dong, Xiao-Yuan. 2008. "Male-Female Wage Discrimination in Chinese Industry: Investigation Using Firm-Level Data." Economics of Transition, 16(1): 85-112.

Zhang, Junsen., Jun Han, Pak-wai, Liu and Yaohui Zhao. 2008. "Trends in the Gender Earnings Differential in Urban China, 1988-2004.” Industrial and Labor Relations Review, 61(2): 224-243. 
Table 1: Frequency distribution over occupational mobility types, by direction and by reason $(\%)$

\begin{tabular}{|c|c|c|c|c|}
\hline & $\begin{array}{l}\text { Full sample } \\
\text { (1) }\end{array}$ & $\begin{array}{l}\text { Men } \\
(2)\end{array}$ & $\begin{array}{l}\text { Women } \\
\text { (3) }\end{array}$ & $\begin{array}{c}\text { Gender gap } \\
\text { (3)-(2) }\end{array}$ \\
\hline \multicolumn{5}{|c|}{ Directions of mobility } \\
\hline $\begin{array}{l}\text { Job stayer } \\
\text { Downward }\end{array}$ & 30.2 & 32.2 & 28.3 & -4.0 \\
\hline $\begin{array}{l}\text { Mobility } \\
\text { Horizontal }\end{array}$ & 28.1 & 25.2 & 30.8 & 5.6 \\
\hline $\begin{array}{l}\text { Mobility } \\
\text { Upward }\end{array}$ & 18.8 & 17.1 & 20.4 & 3.4 \\
\hline Mobility & 22.9 & 25.5 & 20.5 & -4.9 \\
\hline Total & 100.0 & 100.0 & 100.0 & --- \\
\hline Observations & 6,354 & 3,058 & 3,296 & --- \\
\hline \multicolumn{5}{|c|}{ Reasons of mobility } \\
\hline $\begin{array}{l}\text { Career } \\
\text { development }\end{array}$ & 22.2 & 24.4 & 20.2 & -4.2 \\
\hline $\begin{array}{l}\text { Family reasons } \\
\text { Company }\end{array}$ & 15.9 & 11.0 & 20.5 & 9.5 \\
\hline $\begin{array}{l}\text { reassignment } \\
\text { Involuntary }\end{array}$ & 39.6 & 45.1 & 34.4 & -10.7 \\
\hline separation & 17.2 & 14.8 & 19.4 & 4.6 \\
\hline Others & 5.1 & 4.7 & 5.4 & 0.7 \\
\hline Total & 100.0 & 100.0 & 100.0 & --- \\
\hline Observations & 3,099 & 1,499 & 1,600 & ---- \\
\hline
\end{tabular}

Source: All tables are based on the Second Survey on Social Status of Chinese Women undertaken jointly by All China Women Federation and National Statistical Bureau of China in December 2000. 
Table 2: Mean values of explanatory variables

\begin{tabular}{|c|c|c|c|}
\hline & Full sample & Men & Women \\
\hline Age & 37.28 & 37.67 & 36.92 \\
\hline Years of schooling & 9.69 & 9.96 & 9.45 \\
\hline Experience prior to & & & \\
\hline Current job & 13.15 & 13.15 & 13.15 \\
\hline SEI of first job & 48.24 & 48.70 & 47.80 \\
\hline Father's SEI & 46.46 & 46.06 & 46.83 \\
\hline Spouse's SEI & 49.13 & 48.09 & 50.10 \\
\hline Party member & & & \\
\hline prior to current job & 0.11 & 0.15 & 0.07 \\
\hline Number of children & 1.19 & 1.19 & 1.19 \\
\hline $\begin{array}{l}\text { Current job acquired } \\
\text { after } 1996\end{array}$ & 0.30 & 0.26 & 0.33 \\
\hline SOEs \& Public & & & \\
\hline organizations & 0.54 & 0.57 & 0.51 \\
\hline Urban collectives & 0.17 & 0.15 & 0.20 \\
\hline $\begin{array}{l}\text { Private \& foreign } \\
\text { companies }\end{array}$ & 0.06 & 0.06 & 0.06 \\
\hline Other ownership type & 0.23 & 0.22 & 0.23 \\
\hline $\begin{array}{l}\% \text { employment in } \\
\text { public sector }\end{array}$ & 54.44 & 54.50 & 54.39 \\
\hline Northern Coastal & 0.16 & 0.16 & 0.16 \\
\hline Southern Coastal & 0.12 & 0.12 & 0.12 \\
\hline Eastern Coastal & 0.13 & 0.13 & 0.13 \\
\hline North East & 0.13 & 0.13 & 0.14 \\
\hline Mid-Yangze Range & 0.16 & 0.17 & 0.15 \\
\hline Mid-Huanghe Range & 0.13 & 0.13 & 0.13 \\
\hline South West & 0.12 & 0.12 & 0.13 \\
\hline North West & 0.04 & 0.04 & 0.04 \\
\hline Observations & 6,354 & 3,058 & 3,296 \\
\hline
\end{tabular}

Notes: Northern Coastal includes Shandong, Hebei, Beijing and Tianjin; Southern Coastal includes Guangdong, Fujian and Hainan; Eastern Coastal includes Shanghai, Jiangsu and Zhejiang; North East includes Liaoning, Heilongjiang and Jilin; Mid-Yangtze Range includes Hunan, Hubei, Jiangxi and Anhui; Mid-Hunaghe Range includes Shaanxi, Henan, Shanxi and Inner Mongolia; South West includes Guangxi, Yunnan, Sichuan, Chongqing and Guizhou; North West includes Gansu, Tibet and Xinjiang. 
Table 3 Multinomial logit estimates of marginal effects for occupational mobility directions of the full sample

\begin{tabular}{|c|c|c|c|c|}
\hline & Job stayer & Downward & Lateral & Upward \\
\hline \multicolumn{5}{|c|}{ Part I } \\
\hline Gender & -0.038 & 0.055 & 0.034 & -0.050 \\
\hline (Women=1) & $(0.011) * * *$ & $(0.010)^{* * *}$ & $(0.011) * * *$ & $(0.012)^{* * *}$ \\
\hline Pseudo $\mathrm{R}^{2}$ & 0.010 & & & \\
\hline \multicolumn{5}{|c|}{ Part II } \\
\hline Gender & -0.027 & 0.045 & 0.050 & -0.067 \\
\hline (Women=1) & $(0.009)^{* * *}$ & $(0.014)^{* * *}$ & $(0.013)^{* * *}$ & $(0.013)^{* * *}$ \\
\hline \multirow{2}{*}{ Age } & -0.096 & 0.067 & 0.006 & 0.022 \\
\hline & $(0.008)^{* * *}$ & $(0.008) * * *$ & $(0.007)$ & $(0.007) * * *$ \\
\hline $\mathrm{Age}^{2}$ & 0.060 & -0.059 & 0.005 & -0.005 \\
\hline x 100 & $(0.010)^{* * *}$ & $(0.011) * * *$ & (0.009) & $(0.009)$ \\
\hline \multirow[t]{2}{*}{ Years of schooling } & 0.023 & -0.012 & -0.008 & -0.003 \\
\hline & $(0.003)^{* * *}$ & $(0.003)^{* * *}$ & $(0.003)^{* *}$ & $(0.003)$ \\
\hline \multirow[t]{2}{*}{ Experience } & 0.055 & -0.008 & -0.029 & -0.019 \\
\hline & $(0.004) * * *$ & $(0.003)^{* * *}$ & $(0.003)^{* * *}$ & $(0.003) * * *$ \\
\hline Experience $^{2}$ & -0.014 & 0.030 & 0.043 & 0.000 \\
\hline x 100 & $(0.010)$ & $(0.010)^{* * *}$ & $(0.009)^{* * *}$ & $(0.010)$ \\
\hline \multirow[t]{2}{*}{ SEI of first job } & 0.013 & 0.000 & 0.008 & -0.021 \\
\hline & $(0.001)^{* * *}$ & $(0.002)$ & $(0.001)^{* * *}$ & $(0.002) * * *$ \\
\hline \multirow[t]{2}{*}{ Father's SEI } & -0.001 & 0.000 & -0.002 & 0.003 \\
\hline & $(0.001)^{*}$ & $(0.001)$ & $(0.001)^{* * *}$ & $(0.001)^{* * *}$ \\
\hline \multirow[t]{2}{*}{ Spouse's SEI } & -0.001 & -0.002 & 0.000 & 0.003 \\
\hline & $(0.001)$ & $(0.001)^{* *}$ & $(0.001)$ & $(0.001)^{* * *}$ \\
\hline Party member prior to & -0.109 & -0.053 & -0.031 & 0.193 \\
\hline job change & $(0.015)^{* * *}$ & $(0.023)^{* *}$ & $(0.024)$ & $(0.028) * * *$ \\
\hline \multirow[t]{2}{*}{ No. children } & -0.009 & -0.007 & 0.015 & 0.001 \\
\hline & $(0.010)$ & $(0.013)$ & $(0.012)$ & $(0.010)$ \\
\hline \multirow{2}{*}{$\begin{array}{l}\text { Current job acquired } \\
\text { after } 1996\end{array}$} & -0.230 & 0.249 & -0.032 & 0.013 \\
\hline & $(0.014)^{* * *}$ & $(0.012)^{* * *}$ & $(0.015)^{* *}$ & $(0.014)$ \\
\hline \multirow[t]{2}{*}{ Urban collective } & -0.042 & 0.106 & -0.005 & -0.059 \\
\hline & $(0.012)^{* * *}$ & $(0.025)^{* * *}$ & $(0.016)$ & $(0.018) * * *$ \\
\hline \multirow{2}{*}{$\begin{array}{l}\text { Private \& foreign } \\
\text { companies }\end{array}$} & -0.141 & 0.142 & 0.048 & -0.048 \\
\hline & $(0.015)^{* * *}$ & $(0.033)^{* * *}$ & $(0.029)^{*}$ & $(0.018)^{* * *}$ \\
\hline \multirow[t]{2}{*}{ Other ownership type } & -0.120 & 0.147 & 0.032 & -0.059 \\
\hline & $(0.018)^{* * *}$ & $(0.023)^{* * *}$ & $(0.018)^{*}$ & $(0.022) * * *$ \\
\hline \multirow[t]{2}{*}{$\%$ SOE employment } & -0.001 & 0.002 & 0.002 & -0.003 \\
\hline & $(0.002)$ & $(0.002)$ & $(0.001)^{*}$ & $(0.002)^{*}$ \\
\hline \multirow[t]{2}{*}{ Northern Coastal } & -0.061 & 0.064 & -0.052 & 0.050 \\
\hline & $(0.020)^{* * *}$ & $(0.038)^{*}$ & $(0.026)^{* *}$ & $(0.050)$ \\
\hline \multirow[t]{2}{*}{ Southern Coastal } & -0.095 & 0.107 & -0.014 & 0.002 \\
\hline & $(0.044)^{* *}$ & $(0.073)$ & $(0.045)$ & $(0.063)$ \\
\hline \multirow[t]{2}{*}{ Eastern Coastal } & -0.070 & 0.081 & -0.022 & 0.011 \\
\hline & $(0.030)^{* *}$ & $(0.043)^{*}$ & $(0.030)$ & $(0.054)$ \\
\hline \multirow[t]{2}{*}{ North East } & -0.056 & 0.144 & -0.032 & -0.056 \\
\hline & $(0.029)^{*}$ & $(0.037) * * *$ & $(0.031)$ & $(0.042)$ \\
\hline \multirow[t]{2}{*}{ Mid-Yangze Range } & -0.020 & 0.073 & -0.007 & -0.046 \\
\hline & $(0.025)$ & $(0.034)^{* *}$ & $(0.028)$ & $(0.048)$ \\
\hline Mid-Huanghe Range & -0.033 & 0.025 & 0.017 & -0.009 \\
\hline
\end{tabular}




\begin{tabular}{lcccc} 
& $(0.028)$ & $(0.045)$ & $(0.036)$ & $(0.045)$ \\
South West & -0.024 & 0.018 & -0.007 & 0.013 \\
& $(0.019)$ & $(0.028)$ & $(0.029)$ & $(0.043)$ \\
Predict probability & 0.172 & 0.334 & 0.240 & 0.254 \\
Pseudo R & 0.224 & & & \\
Observations & 6,354 & & & \\
\hline
\end{tabular}

Notes: Part I also control for regional effects. The reference group for Part II includes men who did not have party membership prior to current job, acquired the current job after 1996 and worked in the state sector in the north western region. Figures in parentheses are standard errors robust to intra-province correlation. ***,**, and $*$ stand for significance at the level of $1 \%, 5 \%$ and $10 \%$, respectively. 
Table 4 Multinomial logit estimates of marginal effects for occupational mobility directions of job movers

\begin{tabular}{|c|c|c|c|}
\hline \multirow{2}{*}{\multicolumn{4}{|c|}{$\begin{array}{l}\text { Lateral } \\
\text { Part I }\end{array}$}} \\
\hline & & & \\
\hline Gender & 0.037 & -0.003 & -0.035 \\
\hline (Women=1) & $(0.015)^{* * *}$ & $(0.015)$ & $(0.017)^{* *}$ \\
\hline Pseudo $\mathrm{R}^{2}$ & 0.011 & & \\
\hline \multicolumn{4}{|c|}{ Part II } \\
\hline Gender & 0.019 & 0.036 & -0.056 \\
\hline (Women=1) & $(0.019)$ & $(0.020)^{*}$ & $(0.021)^{* * *}$ \\
\hline Gender $x$ job- change & 0.072 & -0.078 & 0.006 \\
\hline after 1996 & $(0.034)^{* *}$ & $(0.030)^{* * *}$ & $(0.029)$ \\
\hline Pseudo $\mathrm{R}^{2}$ & 0.112 & & \\
\hline \multicolumn{4}{|c|}{ Part III } \\
\hline Gender & 0.005 & 0.032 & -0.037 \\
\hline (Women=1) & $(0.021)$ & $(0.020)$ & $(0.023)$ \\
\hline Gender $x$ job- change & 0.091 & -0.077 & -0.014 \\
\hline after 1996 & $(0.038)^{* *}$ & $(0.030)^{* * *}$ & $(0.031)$ \\
\hline Career & -0.029 & -0.103 & 0.132 \\
\hline Development & $(0.038)$ & $(0.035)^{* * *}$ & $(0.047)^{* * *}$ \\
\hline \multirow[t]{2}{*}{ Family reasons } & -0.022 & -0.025 & 0.046 \\
\hline & $(0.041)$ & $(0.039)$ & $(0.047)$ \\
\hline Company & -0.149 & -0.035 & 0.184 \\
\hline reassignment & $(0.043)^{* * *}$ & $(0.036)$ & $(0.046)^{* * *}$ \\
\hline \multirow[t]{2}{*}{ Involuntary separation } & 0.270 & -0.135 & -0.135 \\
\hline & $(0.042)^{* * *}$ & $(0.029)^{* * *}$ & $(0.048) * * *$ \\
\hline \multirow[t]{2}{*}{ Age } & 0.010 & 0.003 & -0.014 \\
\hline & $(0.013)$ & $(0.010)$ & $(0.009)$ \\
\hline $\mathrm{Age}^{2}$ & -0.012 & -0.965 & 0.022 \\
\hline x 100 & $(0.016)$ & $(0.012)$ & $(0.011)^{*}$ \\
\hline \multirow[t]{2}{*}{ Years of schooling } & -0.011 & -0.001 & 0.012 \\
\hline & $(0.004)^{* * *}$ & $(0.004)$ & $(0.004)^{* * *}$ \\
\hline \multirow[t]{2}{*}{ Experience } & 0.012 & -0.013 & 0.001 \\
\hline & $(0.005)^{* *}$ & $(0.003) * * *$ & $(0.004)$ \\
\hline Experience $^{2}$ & -0.030 & 0.044 & -0.014 \\
\hline x 100 & $(0.014)^{* *}$ & $(0.010)^{* * *}$ & $(0.013)$ \\
\hline \multirow[t]{2}{*}{ SEI of first job } & 0.029 & 0.014 & -0.043 \\
\hline & $(0.002)^{* * *}$ & $(0.001)^{* * *}$ & $(0.002)^{* * *}$ \\
\hline \multirow[t]{2}{*}{ Father's SEI } & -0.001 & -0.002 & 0.003 \\
\hline & $(0.001)$ & $(0.001)^{* *}$ & $(0.002)^{* *}$ \\
\hline \multirow[t]{2}{*}{ Spouse's SEI } & -0.006 & 0.001 & 0.005 \\
\hline & $(0.001)^{* * *}$ & $(0.001)$ & $(0.002)^{* * *}$ \\
\hline \multirow[t]{2}{*}{ Party member } & -0.095 & -0.086 & 0.180 \\
\hline & $(0.027)^{* * *}$ & $(0.029)^{* * *}$ & $(0.033)^{* * *}$ \\
\hline current job acquired & 0.079 & -0.040 & -0.040 \\
\hline after 1996 & $(0.029) * * *$ & $(0.029)$ & $(0.028)$ \\
\hline \multirow[t]{2}{*}{ Urban collective } & 0.097 & 0.001 & -0.097 \\
\hline & $(0.032)^{* * *}$ & $(0.024)$ & $(0.020)^{* * *}$ \\
\hline \multirow{2}{*}{$\begin{array}{l}\text { Private } \& \text { foreign } \\
\text { companies }\end{array}$} & 0.139 & -0.018 & -0.121 \\
\hline & $(0.038)^{* * *}$ & $(0.030)$ & $(0.022)^{* * *}$ \\
\hline
\end{tabular}




$\begin{array}{lccc}\text { Other ownership type } & 0.172 & -0.023 & -0.149 \\ & (0.027)^{* * *} & (0.027) & (0.024)^{* * *} \\ \text { \% SOE employment } & 0.005 & 0.000 & -0.005 \\ & (0.002)^{* * *} & (0.001) & (0.003)^{* *} \\ \text { Regions } & \text { yes } & \text { yes } & \text { yes } \\ \text { Predicted probability } & 0.431 & 0.248 & 0.321 \\ \text { Pseudo R } & 0.151 & & \\ \text { Observations } & 3,097 & & \end{array}$

Notes: Part I controls gender and regional effects only, and Part II includes all the explanatory variables except those for mobility reasoning. The reference group for Part III consists of men who changed jobs for unknown reason, did not have party membership prior to current job, acquired current job after 1996, and worked in the public sector in the north western region. Figures in parentheses are standard errors robust to intra-province correlation. ***, **, and * stand for significance at the level of $1 \%, 5 \%$ and $10 \%$, respectively. 
Table 5. Multinomial logit estimates of marginal effects for occupational mobility directions of job movers, by type of job match

\begin{tabular}{|c|c|c|c|c|c|c|}
\hline & \multicolumn{3}{|c|}{ Administratively matched } & \multicolumn{3}{|c|}{ Non-administratively matched } \\
\hline & Downward & Lateral & Upward & Downward & Lateral & Upward \\
\hline Gender & 0.038 & 0.069 & -0.106 & -0.023 & 0.021 & 0.001 \\
\hline$($ Women=1) & $(0.035)$ & $(0.032)^{* *}$ & $(0.033) * * *$ & $(0.028)$ & $(0.030)$ & $(0.034)$ \\
\hline \multicolumn{7}{|l|}{ Gender x job- } \\
\hline change after & 0.091 & -0.006 & -0.085 & 0.098 & -0.095 & -0.003 \\
\hline 1996 & $(0.085)$ & $(0.073)$ & $(0.064)$ & $(0.036)^{* * *}$ & $(0.038)^{* * *}$ & $(0.030)$ \\
\hline Career & & & & -0.055 & -0.072 & 0.127 \\
\hline Development & ---- & ---- & ---- & $(0.041)$ & $(0.033)^{* *}$ & $(0.043) * * *$ \\
\hline Family & & & & -0.029 & -0.016 & 0.046 \\
\hline reasons & ---- & ---- & ---- & $(0.046)$ & $(0.036)$ & $(0.042)$ \\
\hline Involuntary & & & & 0.253 & -0.135 & -0.118 \\
\hline separation & ---- & ---- & ---- & $(0.044) * * *$ & $(0.027)^{* * *}$ & $(0.045)^{* * * *}$ \\
\hline \multirow[t]{2}{*}{ Age } & -0.020 & 0.000 & 0.020 & 0.017 & 0.001 & -0.018 \\
\hline & $(0.022)$ & $(0.019)$ & $(0.017)$ & $(0.015)$ & $(0.011)$ & $(0.012)$ \\
\hline $\mathrm{Age}^{2}$ & 0.020 & -0.005 & -0.015 & -0.017 & -0.009 & 0.000 \\
\hline x 100 & $(0.027)$ & $(0.024)$ & $(0.021)$ & $(0.000)$ & $(0.014)$ & $(0.000)^{*}$ \\
\hline Years of & -0.025 & 0.003 & 0.022 & -0.005 & -0.002 & 0.008 \\
\hline schooling & $(0.006)^{* * *}$ & $(0.008)$ & $(0.007) * * *$ & $(0.006)$ & $(0.005)$ & $(0.004)^{* *}$ \\
\hline \multirow[t]{2}{*}{ Experience } & 0.009 & -0.017 & 0.008 & 0.015 & -0.009 & -0.006 \\
\hline & $(0.006)$ & $(0.005)^{* * *}$ & $(0.006)$ & $(0.007)^{* *}$ & $(0.005)^{*}$ & $(0.003)^{* *}$ \\
\hline Experience $^{2}$ & -0.012 & 0.047 & -0.035 & -0.053 & 0.043 & 0.000 \\
\hline x 100 & $(0.016)$ & $(0.017)^{* * *}$ & $(0.018)^{*}$ & $(0.001)^{* * *}$ & $(0.016) * * *$ & $(0.000)$ \\
\hline \multirow[t]{2}{*}{ SEI of first job } & 0.022 & 0.025 & -0.048 & 0.033 & 0.007 & -0.040 \\
\hline & $(0.002) * * *$ & $(0.002) * * *$ & $(0.004) * * *$ & $(0.003) * * *$ & $(0.002) * * *$ & $(0.002) * * *$ \\
\hline \multirow[t]{2}{*}{ Father's SEI } & -0.003 & -0.002 & 0.005 & 0.000 & -0.002 & 0.002 \\
\hline & $(0.002)^{* *}$ & $(0.002)$ & $(0.002)^{* *}$ & $(0.002)$ & $(0.001)^{* * *}$ & $(0.002)$ \\
\hline \multirow[t]{2}{*}{ Spouse's SEI } & -0.007 & -0.002 & 0.009 & -0.005 & 0.003 & 0.002 \\
\hline & $(0.002)^{* * *}$ & $(0.002)$ & $(0.003) * * *$ & $(0.002)^{* *}$ & $(0.001)^{* *}$ & $(0.002)$ \\
\hline \multirow[t]{2}{*}{ Party member } & -0.099 & -0.095 & 0.195 & -0.025 & -0.073 & 0.098 \\
\hline & $(0.031)^{* * *}$ & $(0.040)^{* *}$ & $(0.041)^{* * *}$ & $(0.037)$ & $(0.030) * *$ & $(0.039)^{* *}$ \\
\hline \multicolumn{7}{|l|}{ Current job } \\
\hline acquired after & 0.088 & -0.093 & 0.005 & 0.060 & -0.018 & -0.042 \\
\hline 1996 & $(0.059)$ & $(0.055)^{*}$ & $(0.053)$ & $(0.031) * *$ & $(0.038)$ & $(0.036)$ \\
\hline Urban & 0.077 & 0.017 & -0.095 & 0.081 & 0.001 & -0.082 \\
\hline collective & $(0.047)^{*}$ & $(0.040)$ & $(0.042)^{* *}$ & $(0.035)^{* *}$ & $(0.031)$ & $(0.034)^{* *}$ \\
\hline Private \& & 0.190 & -0.224 & 0.034 & 0.130 & 0.001 & -0.131 \\
\hline foreign firms & $(0.082)^{* *}$ & $(0.051) * * *$ & $(0.076)$ & $(0.037)^{* * * *}$ & $(0.027)$ & $(0.026) * * *$ \\
\hline Other types of & 0.379 & -0.094 & -0.286 & 0.169 & -0.029 & -0.140 \\
\hline ownership & $(0.055) * * *$ & $(0.061)$ & $(0.049) * * *$ & $(0.028)^{* * * *}$ & $(0.030)$ & $(0.028)^{* * * *}$ \\
\hline$\% \mathrm{SOE}$ & 0.005 & -0.001 & -0.004 & 0.003 & 0.003 & -0.006 \\
\hline employment & $(0.004)$ & $(0.002)$ & $(0.004)$ & $(0.002)$ & $(0.003)$ & $(0.003)^{* *}$ \\
\hline Regions & yes & yes & yes & yes & yes & yes \\
\hline
\end{tabular}




\begin{tabular}{lcccccc} 
Predicted & 0.286 & 0.298 & 0.415 & 0.535 & 0.208 & 0.256 \\
probability & & & & & & \\
Pseudo R & & 0.158 & & & 0.142 & \\
Observations & 1,227 & & & 1,872 & & \\
\hline
\end{tabular}

Notes: The administratively matched sample includes those who changed occupations through company reassignment, and the non-administratively matched sample consists of those who changed occupations for personal development, family and other reasons or as a result of involuntary separation. The reference group is men who did not have party membership prior to current job, acquired current job after 1996, and work in the public section in the north western region for the first sample and also includes those who changed jobs for other reasons for the second one. Figures in parentheses are standard errors robust to intra-province correlations. ***, $* *$, and $*$ stand for significance at the level of $1 \%, 5 \%$ and $10 \%$, respectively. 
Appendix: The SEI scores of 79 3-digit occupational categories

\begin{tabular}{|c|c|c|c|}
\hline Occupation & $\begin{array}{l}\text { Education } \\
\text { (years) }\end{array}$ & $\begin{array}{l}\text { Average } \\
\text { Income(Yuan) }\end{array}$ & SEI \\
\hline Faculties in Universities & 14.55 & 1087 & 68.15 \\
\hline Chiefs of Different-level Communist Party & 12.62 & 1578 & 67.63 \\
\hline Chiefs of the Enterprises & 11.16 & 2706 & 65.82 \\
\hline Designers of airplanes and Ships & 12.67 & 1757 & 65.5 \\
\hline Chiefs of Different-level Governments & 12.33 & 1928 & 65.33 \\
\hline Engineers & 12.93 & 1465 & 64.71 \\
\hline Chiefs of Governmental Affiliated Organizations & 11.99 & 1552 & 61.93 \\
\hline Journalists and Writers & 12.62 & 1006 & 60.91 \\
\hline Other teachers & 11.03 & 1850 & 60.33 \\
\hline Doctors & 12.15 & 947 & 58.92 \\
\hline Lawyers and Other Law Professionals & 11.83 & 1130 & 58.9 \\
\hline Teachers in Primary Schools & 12.33 & 762 & 58.47 \\
\hline Science researchers & 11.6 & 1193 & 58.45 \\
\hline Environment Supervision Technician & 12.0 & 700 & 56.94 \\
\hline Other Technician & 11.21 & 1067 & 56.34 \\
\hline Healthcare assistants & 10.78 & 688 & 56.27 \\
\hline Policemen & 11.47 & 862 & 56.03 \\
\hline Athletes & 11.0 & 1125 & 55.95 \\
\hline Professional in Financial Trade & 11.1 & 1016 & 55.67 \\
\hline Staffs at Post offices & 10.48 & 1056 & 53.74 \\
\hline Clerks & 10.92 & 712 & 53.25 \\
\hline Chiefs of other parties & 10.77 & 739 & 52.86 \\
\hline Professionals of trade & 10.62 & 778 & 52.57 \\
\hline Staffs at Agencies & 10.0 & 1090 & 52.25 \\
\hline Other Healthcare Professionals & 10.83 & 541 & 51.92 \\
\hline Professionals of Agricultural Industry & 10.6 & 626 & 51.61 \\
\hline Projectionists & 10.0 & 678 & 49.82 \\
\hline Chiefs of NGOs & 9.2 & 481 & 49.76 \\
\hline Assemblers of Machinery and Electronics & 10.06 & 584 & 49.48 \\
\hline Staffs of Metrology and Testing Technology & 9.85 & 664 & 49.22 \\
\hline Forestry Workers & 9.93 & 608 & 49.16 \\
\hline Healthcare Assistants & 9.88 & 609 & 48.98 \\
\hline Workers of Electronic Components & 9.79 & 654 & 48.93 \\
\hline Firemen & 9.85 & 587 & 48.76 \\
\hline Workers in Tobacco factories & 8.91 & 1133 & 48.69 \\
\hline Workers in Chemistry Industry & 9.87 & 535 & 48.52 \\
\hline Workers in Pharmaceutical enterprises & 8.5 & 1345 & 48.5 \\
\hline Artists & 9.87 & 512 & 48.38 \\
\hline Army & 9.33 & 751 & 47.92 \\
\hline Nursery School Teachers & 9.50 & 631 & 47.79 \\
\hline Staffs of Electricity Installation and Maintenance & 9.32 & 734 & 47.78 \\
\hline
\end{tabular}




\begin{tabular}{|c|c|c|c|}
\hline Workers of Teaching facilities & 9.38 & 546 & 46.86 \\
\hline Workers of Construction Materials & 9.10 & 692 & 46.77 \\
\hline Staffs of Transportation Industry & 8.89 & 790 & 46.59 \\
\hline Repairmen of Machinery Equipment & 9.15 & 612 & 46.45 \\
\hline Agricultural Machinery Operators & 9.29 & 522 & 46.41 \\
\hline Staffs of realty management & 9.12 & 600 & 46.29 \\
\hline Staffs of Storage Industry & 9.24 & 513 & 46.19 \\
\hline Workers of Metal Smelt & 9.13 & 559 & 46.09 \\
\hline Servants of Transportation Industry & 8.83 & 726 & 46.02 \\
\hline Other Staffs in Trade and Service Industry & 8.90 & 683 & 46.02 \\
\hline Other Staffs in Production and Transportation & 8.86 & 665 & 45.77 \\
\hline Workers of Machinery Processing Industry & 9.05 & 512 & 45.53 \\
\hline Hunters & 9.38 & 298 & 45.40 \\
\hline Salesman & 8.63 & 694 & 45.13 \\
\hline Staffs of Community Services Industry & 8.68 & 624 & 44.87 \\
\hline Staffs of Mineral Exploration & 8.87 & 499 & 44.83 \\
\hline Servants at Hotels, Travel agents, Gym & 8.8 & 530 & 44.74 \\
\hline Other Staffs in Trade and Service Industry & 8.75 & 538 & 44.63 \\
\hline Craftworks Producers & 9.00 & 366 & 44.49 \\
\hline Workers in Textile, Printing and Dyeing & 8.63 & 442 & 43.64 \\
\hline Other staffs of living services & 8.31 & 613 & 43.55 \\
\hline Builders & 8.17 & 678 & 43.43 \\
\hline Cooks & 8.21 & 655 & 43.43 \\
\hline Workers in Printing Industry & 8.4 & 486 & 43.1 \\
\hline Other Agricultural Workers & 8.70 & 287 & 42.98 \\
\hline Workers of Glass and Porcelain Processing & 8.30 & 492 & 42.77 \\
\hline Workers in Food Industry & 8.13 & 482 & 42.14 \\
\hline Poultry Producers & 7.72 & 722 & 42.13 \\
\hline Paper Making Workers & 8.16 & 420 & 41.86 \\
\hline Wood Processing Workers & 7.81 & 602 & 41.73 \\
\hline Waiters and Waitress & 7.86 & 460 & 41.04 \\
\hline Workers of Rubbers and Plastic & 7.89 & 314 & 40.31 \\
\hline Other Kind of Servants in Restaurant & 7.59 & 485 & 40.26 \\
\hline Tailors & 7.58 & 396 & 39.68 \\
\hline Packagers & 7.54 & 407 & 39.64 \\
\hline Unskilled Workers & 7.12 & 387 & 38.04 \\
\hline Fishery Workers & 7.00 & 437 & 37.91 \\
\hline Farmers & 6.78 & 293 & 36.28 \\
\hline
\end{tabular}

Notes: the SEI scores are derived for each 3-digit occupation using the following formula provided by $\operatorname{Li}(2005): \mathrm{SEI}=10.868+3.496 \overline{x_{1}}+0.589 \bar{x}_{2}$, where $\bar{x}_{1}$ and $\bar{x}_{2}$ are the mean value of years of schooling and 1999 monthly income of each occupation, respectively. 